\title{
Efek Berkumur Sari Buah Tomat (Solanum lycopersicum L.) Terhadap Indeks Plak Gigi
}

\author{
Egi $M^{1}$, Soegiharto $\mathrm{GS}^{1,}$, Evacuasiany $E^{1}$ \\ 1. Falkutas Kedokteran Gigi, Universitas Kristen Maranatha, 40164, Indonesia \\ Email: marlithaegi321@gmail.com
}

\begin{abstract}
Abstrak
Penyakit periodontal merupakan urutan tertinggi dari penyakit gigi dan mulut di Indonesia. Plak gigi merupakan faktor etiologi yang menjadi penyebab terjadinya penyakit periodontal. Plak gigi merupakan lapisan biofilm yang terdiri dari glikoprotein saliva, polimer ekstraseluler dan bakteri dimana salah satu bakteri utama dalam plak gigi adalah Streptococcus mutans. Pembentukan plak gigi dapat dicegah dengan kontrol plak meliputi kontrol mekanis dan kontrol kimiawi, salah satunya penggunaan obat kumur menggunakan bahan alami yaitu sari buah tomat. Penelitian ini bertujuan untuk mengetahui efek berkumur sari buah tomat (Solanum lycopersicum L.) terhadap indeks plak gigi.

Rancangan penelitian ini berupa eksperimental semu, dengan desain pre-test dan post-test yang bersifat komparatif. Subjek penelitian berjumlah 33 orang. Pengukuran indeks plak gigi dilakukan enam kali, yaitu sebelum dan setelah berkumur sari buah tomat pada hari ke-1, ke-3 dan ke-7. Indeks plak gigi diukur menggunakan metode $O$ 'Leary. Analisis data dilakukan dengan paired t-test dan Wilcoxon test dengan $\alpha=0.05$.

Hasil penelitian rerata penurunan indeks plak gigi setelah berkumur sari buah tomat (Solanum lycopersicum L.) pada hari ke-1 sebesar 13,67, hari ke-3 sebesar 11,03 dan hari ke-7 sebesar 11,07. Hasil analisis data didapatkan nilai $\mathrm{p}<0,05$ berarti terdapat perbedaan presentasi rata-rata indeks plak gigi sebelum dan sesudah berkumur sari buah tomat (Solanum lycopersicum L.) yang signifikan.

Simpulan penelitian ini adalah berkumur dengan sari buah tomat (Solanum lycopersicum L.) memiliki efek menurunkan indeks plak gigi.
\end{abstract}

\section{The Effect of Tomato Juice Gargle (Solanum lycopersicum L.) to Dental Plaque Index Abstract}

Periodontal disease is the highest level of oral cavity disease in Indonesia. Plaque on the teeth is an etiological factor that causes periodontal disease. Dental plaque is a biofilm consisting of salivary glycoproteins, extracellular polymer and bacteria which one of the main bacteria in dental plaque is Streptococcus mutans. The formation of dental plaque can be prevented by the control of plaque as well as mechanical control and chemical control, like rinsing with natural ingredient such as tomato. This research aims to find effect of tomato juice gargle (Solanum lycopersicum L.) to dental plaque index.

The study design was a quasi-experimental research with a comparative pre -test and post-test design. 33 people as objects of this research. The measurement of plaque was done six times, before and after gargle with tomato juice on the 1st, 3rd and 7 th days. Dental plaque index measured by O'Leary method. Data analysis was run by paired $t$-test and Wilcoxon test with $\alpha=0,05$.

The results showed that average decrease of dental plaque index after gargle with 
tomato juice (Solanum lycopersicum L.) were 13,67 on the 1st day, 11,03 on the 3rd day and 11,07 on the 7th day. The result of data analysis obtained p-value <0,05 means that there was a significant difference between the average of dental plaque index before and after gargle with tomato juice (Solanum lycopersicum L.).

The conclusion of this study was gargle with tomato juice (Solanum lycopersicum L.) could decrease dental plaque index.

Keywords: dental plaque; plaque index; tomato juice (Solanum lycopersicum L.)

\section{Pendahuluan}

Kesehatan gigi dan mulut merupakan bagian integral kesehatan secara keseluruhan dan merupakan salah satu sendi kehidupan sehingga perlu dibudidayakan di seluruh masyarakat. Kondisi ini dapat tercapai dengan melakukan perawatan gigi yang tepat. Keadaan oral hygiene yang buruk, seperti adanya plak, kalkulus dan stain, banyak karies gigi, keadaan tidak bergigi atau tidak ada gigi sama sekali, dapat menimbulkan masalah dalam kehidupan sehari-hari. ${ }^{1}$

Penyakit periodontal banyak terjadi di negara maju dan negara berkembang dan mempengaruhi sekitar $20-50 \%$ populasi dunia. ${ }^{2}$ Berdasarkan survei yang dilakukan National Institute Of Dental Research (NIDR) di Indonesia, penyakit periodontal menduduki urutan kedua utama yang masih merupakan masalah di masyarakat. Di Indonesia penyakit periodontal merupakan penyakit gigi dan mulut yang terbanyak diderita masyarakat yaitu sebesar $70 \% .{ }^{3}$ Loe et al., mengemukakan pentingnya peran plak gigi sebagai faktor etiologi yang menjadi penyebab terjadinya penyakit periodontal. $^{4}$

Plak gigi adalah lapisan biofilm yang melekat kuat pada permukaan gigi, restorasi dan protesa. Plak terdiri dari bakteri, glikoprotein saliva dan polimer ekstraseluler. ${ }^{5,6}$ Plak merupakan kumpulan dari mikroba kompleks yang terdiri atas sel epitel, leukosit, makrofag dan sampai 400 spesies bakteri. Plak juga mengandung komponen anorganik seperti kalsium dan fosfor yang berasal dari air liur. ${ }^{7}$

Proses pembentukan plak dibagi menjadi 3 tahap yaitu pembentukan pelikel, perlekatan dan kolonisasi awal mikroorganisme, kolonisasi sekunder dan pematangan plak. Pembentukan plak diawali dengan pembentukan pelikel gigi dimana pada tahap ini permukaan gigi akan dilapisi oleh pelikel glikoprotein. Pelikel tersebut berasal dari saliva, cairan sulkus, produk sel bakteri dan debris, dimana pelikel membantu meningkatkan adhesi atau perlekatan bakteri. Tahap kedua adalah kolonisasi awal oleh mikroba fakultatif gram positif yaitu Streptococcus mutans, Streptococcus sanguis, Streptococcus mitis dan Actinomyces viscosus. Bakteri ini melekat secara berbeda pada permukaan gigi yang dilapisi pelikel dimana beberapa bakteri memiliki struktur perlekatan spesifik seperti zat polimer ekstraseluler, yang memungkinkan mereka untuk melekat cepat pada permukaan karena adanya interaksi reseptor pelikel gigi dan adesi dari permukaan bakteri. Tahap terakhir adalah kolonisasi sekunder dan maturasi mikroba. P. intermedia, $P$. gingivalis, $F$. Nucleatum merupakan bakteri kolonisasi sekunder yang pada awalnya tidak mengkolonisasi permukaan gigi yang bersih atau dilapisi pelikel. Bakteri ini melekat pada sel bakteri yang sudah ada dalam 
masa plak. Pada fase ini, ada koagregasi, yang merupakan kemampuan berbagai spesies mikroba plak untuk melekat satu sama lain.2Fusobacterium nucleatum diyakini menjadi penyambung yang penting antara kolonisasi awal dan sekunder selama pematangan plak. ${ }^{8}$

Bakteri utama dalam plak gigi adalah Streptococcus sanguis, Streptococcus mutans dan Actinomyces viscosus. Studi lain menunjukan bahwa pada awal formasi atau pembentukan plak gigi, Streptococcus mutans, Streptococcus sanguis, Streptococcus mitis, Streptococcus salivarius paling banyak ditemukan. 9,10

Streptococcus mutans telah lama terlibat dalam pembentukan plak gigi dimana menempel dengan ikatan hidrofobik ke permukaan enamel. ${ }^{11}$ Streptococcus mutans mampu mensintesis polisakarida ekstraseluler karena bakteri ini mempunyai enzim glukosiltransferase (GTF) yang terdapat pada dinding sel bakteri Streptococcus mutans yang dapat mengatalisis sintesis glukan dari sukrosa. ${ }^{12}$ Glukan merupakan sumber energi utama bagi bakteri dan memperkuat perlekatan permukaan bakteri pada komponen pelikel gigi. 13

Cara menjaga kebersihan gigi dan mulut adalah dengan pengendalian plak yang melekat pada permukaan gigi atau gingiva dan membersihkan plak gigi secara teratur. Saat menghambat pembentukan plak, maka secara langsung akan menghambat pembentukan kalkulus, sehingga jaringan periodontal menjadi sehat. ${ }^{14}$ Pengendalian plak yang pokok yaitu dengan menyikat gigi secara teratur dan dapat ditambahkan dengan obat kumur. Menyikat gigi secara teratur lebih efektif, tetapi berkumur dapat menjadi alternatif dalam menekan dan menghambat terjadinya plak gigi. Pengendalian plak dengan larutan kumur dapat menggunakan bahan seperti chlorhexidine dan dapat juga menggunakan bahan alami. ${ }^{15}$ Ketertarikan untuk menggunakan bahan alami selain bahan kimia meningkat secara drastis dan banyak orang berpindah ke pengobatan alami untuk perawatan kesehatan karena lebih efektif, tidak beracun, ekonomis, dan biasanya memiliki efek samping yang minimal. ${ }^{16}$

Tomat (Solanum lycopersicum L.) merupakan buah segar keempat yang paling banyak dikonsumsi dan merupakan buah olahan yang paling banyak dikonsumsi di Amerika. ${ }^{17}$ Tomat (Solanum lycopersicum L.) yang sebenarnya merupakan buah dan bukan sayuran, mengandung berbagai manfaat kesehatan bagi tubuh. ${ }^{18}$ Konsumsi buah tomat (Solanum lycopersicum L.) telah dikaitkan dengan penurunan risiko proses inflamasi, kanker dan penyakit kronis termasuk penyakit kardiovaskular (CVD) seperti penyakit jantung koroner, hipertensi, diabetes, dan obesitas. Tomat (Solanum lycopersicum L.) mengandung beberapa kandungan bioaktif seperti lycopene, tannin, lutein, beta carotene dan vitamin yang bersifat anti-inflamasi, antibakteri, antioksidan, dan zat antikanker.

Salah satu kandungan yang terdapat pada tomat (Solanum lycopersicum L.) adalah tannin. ${ }^{19}$ Tannin telah lama diketahui memiliki sifat antibakteri dalam pembentukan biofilm dan aktifitasantibiofilm dalam suatu kolonisasi. Telah terbukti juga tannin mencegah perlekatan $S$. mutans ke permukaan gigi dengan cara mengurangi hidrofobisitas dari badan sel bakteri. ${ }^{20,21}$ Tannin memiliki manfaat dalam menghambat pertumbuhan S. mutans, yang merupakan faktor utama dalam pembentukan plak gigi. 22 
Kandungan lain yang terdapat pada tomat (Solanum lycopersicum L.) adalah flavonoid. Flavonoid telah diketahui memiliki efek antibakteri bakteriostatik bahkan pada konsentrasi yang rendah. $^{23}$ Flavonoid dapat menghambat enzim glukosiltransferase (GTF) sehingga mengurangi perlekatan dan pembentukan koloni Streptococcus mutans yang mengatalisis sintesis glukan dari sukrosa. ${ }^{12,19}$ Menurut penelitian, ditemukan bahwa flavonoid menghambat pembentukan plak dengan menunjukan penurunan yang signifikan pada streptokokus gram positif. ${ }^{24}$

Sampai saat ini belum terdapat penelitian mengenai pengaruh buah tomat (Solanum lycopersicum L.) terhadap plak dalam rongga mulut, sehingga berdasarkan latar belakang tersebut, peneliti tertarik untuk melakukan penelitian mengenai efek berkumur sari buah tomat terhadap indeks plak gigi. Identifikasi masalah penelitian ini adalah apakah terdapat efek berkumur dengan sari buah tomat (Solanum lycopersicum L.) terhadap indeks plak gigi. Tujuan penelitian ini adalah untuk menilai peranan sari buah tomat (Solanum lycopersicum L.) dalam menurunkan indeks plak gigi.

\section{Metode Penelitian}

Alat yang digunakan dalam penelitian ini: Sarung tangan lateks; Sarung tangan plastik; Masker; Alat dasar (kaca mulut, sonde, pinset, ekskavator); Baki; Timer; Slabber; Sikat gigi; Gelas ukur; Gelas kumur; Wadah tertutup; Wadah sterofoam; Pisau; Tissue; Kassa steril; Cheek retractor; Timbangan elektronik; Alat tulis; Corong; dan Form penelitian.

Bahan yang digunakan dalam penelitian ini: Sari buah tomat (Solanum lycopersicum L.);

Disclosing solution; Pasta gigi; dan Es batu.

Populasi penelitian adalah mahasiswa di Program Studi S1 Fakultas Kedokteran Gigi Universitas Kristen Maranatha yang memenuhi kriteria inklusi: Terdaftar sebagai mahasiswa Fakultas Kedokteran Gigi Universitas Kristen Maranatha; Bersedia menandatangani informed consent; Kooperatif; Bersedia mendapat perlakuan sesuai dengan alur penelitian; dan Memiliki gigi permanen lengkap (molar ketiga tidak diperhitungkan, tidak boleh ada kehilangan gigi 1 atau lebih). Kriteria eksklusinya meliputi: Subjek yang menggunakan alat ortodontik cekat; Alergi produk herbal selama penelitian; Subjek yang mempunyai penyakit sistemik seperti diabetes; Subjek yang sedang mengalami gingivitis atau periodontitis; Subjek yang memiliki kebiasaan merokok; Subjek dengan karies kelas 2, 3, 4 dan 5 yang belum direstorasi; Subjek yang menggunakan protesa gigi cekat dan lepasan; Mengkonsumsi antibiotik; dan Subjek yang memiliki crowding berat.

Penelitian ini merupakan penelitian eksperimental semu dengan desain penelitian one group pre test-post test yang bersifat komparatif.

Data yang diperoleh dari penelitian ini dimasukan ke dalam tabel untuk pengamatan dan pengkajian data. Data dianalisis dan diolah dengan menggunakan perangkat jaringan lunak SPSS yaitu untuk melihat perbedaan pre test-post test menggunakan uji $\mathrm{T}$ berpasangan.

\section{Hasil}

Penelitian mengenai efek berkumur sari buah tomat (Solamun lycopercsicum L.) 
terhadap indeks plak gigi telah dilakukan pada mahasiswa di program studi S1 Fakultas Kedokteran Gigi Universitas Kristen Maranatha merupakan penelitian eksperimental semu. Jumlah subjek penelitian yang memenuhi kriteria inklusi dan eksklusi adalah 33 subjek. Indeks plak subjek penelitian dihitung terlebih dahulu dengan menggunakan metode O'leary sebelum diberi perlakuan. Bahan yang digunakan adalah sari buah tomat (Solamun lycopercsicum L.) sebanyak $50 \mathrm{ml}$, kemudian subjek berkumur selama 1 menit dengan 2 kali berkumur, frekuensi 1 kali sehari, 2 jam setelah makan siang selama 7 hari berturut-turut. Selanjutnya, dilakukan kembali pengukuran indeks plak gigi dengan menggunakan metode O'leary dimana pengukuran dilakukan kembali pada hari ke-3 dan ke-7.

Uji Perbandingan Indeks Plak Gigi Sebelum dan Sesudah Berkumur Sari Buah Tomat (Solamun lycopercsicum L.)

Analisis ini digunakan untuk melihat apakah terdapat perbedaan indeks plak gigi yang signifikan setelah menggunakan sari buah tomat sebelum dan setelah diberi perlakuan.

\section{$\underline{\text { Analisis Deskriptif }}$}

Tabel 1 menunjukkan bahwa subjek pada hari ke-1 memiliki rata-rata indeks plak sebelum berkumur dengan sari buah tomat (Solamun lycopercsicum L.) sebesar 61,33 dengan nilai standar deviasi sebesar 15,569 dan rata-rata indeks plak sesudah berkumur dengan sari buah tomat (Solamun lycopercsicum L.) sebesar 47,66 dengan nilai standar deviasi sebesar 17,755.

Tabel 1 Rata-rata Indeks Plak Gigi Sebelum dan Sesudah Berkumur dengan Sari Buah Tomat (Solamun lycopercsicum L.) Hari ke-1

\begin{tabular}{clll}
\hline $\begin{array}{c}\text { Indeks plak gigi } \\
\text { hari ke-1 }\end{array}$ & $\mathbf{N}$ & $\begin{array}{l}\text { St. } \\
\text { Deviasi }\end{array}$ & $\begin{array}{l}\text { Rata- } \\
\text { rata }\end{array}$ \\
\hline Sebelum & 33 & 15,569 & 61,329 \\
Sesudah & 33 & 17,755 & 47,664 \\
\hline
\end{tabular}

Tabel 2 menunjukkan bahwa subjek pada hari ke-3 memiliki rata-rata indeks plak sebelum berkumur dengan sari buah tomat (Solamun lycopercsicum L.) sebesar 50.098 dengan nilai standar deviasi sebesar 12,326 dan rata-rata indeks plak sesudah berkumur dengan sari buah tomat (Solamun lycopercsicum L.) sebesar 39,066 dengan nilai standar deviasi sebesar 13,543. Tabel 2 Rata-rata Indeks Plak Gigi Sebelum dan Sesudah Berkumur dengan Sari Buah Tomat (Solamun lycopercsicum L.) Hari ke-3

\begin{tabular}{clll}
\hline $\begin{array}{c}\text { Indeks plak gigi } \\
\text { hari ke-3 }\end{array}$ & $\mathbf{N}$ & $\begin{array}{l}\text { St. } \\
\text { Deviasi }\end{array}$ & $\begin{array}{l}\text { Rata- } \\
\text { rata }\end{array}$ \\
\hline $\begin{array}{c}\text { Sebelum } \\
\text { Sesudah }\end{array}$ & 33 & 12,326 & 50,098 \\
& 33 & 13,543 & 39,066 \\
\hline
\end{tabular}

Tabel 3 menunjukkan bahwa subjek pada hari ke-7 memiliki rata-rata indeks plak 
sebelum berkumur dengan sari buah tomat (Solamun lycopercsicum L.) sebesar 45,184 dengan nilai standar deviasi sebesar 10,166 dan rata-rata indeks plak sesudah berkumur dengan sari buah tomat (Solamun lycopercsicum L.) sebesar 34,091 dengan nilai standar deviasi sebesar 9,379.

Tabel 3 Rata-rata Indeks Plak Gigi Sebelum dan Sesudah Berkumur dengan Sari Buah Tomat (Solamun lycopercsicum L.) Hari ke-7

\begin{tabular}{clll}
\hline $\begin{array}{c}\text { Indeks plak gigi } \\
\text { hari ke-7 }\end{array}$ & $\mathbf{N}$ & $\begin{array}{l}\text { St. } \\
\text { Deviasi }\end{array}$ & $\begin{array}{l}\text { Rata- } \\
\text { rata }\end{array}$ \\
\hline $\begin{array}{c}\text { Sebelum } \\
\text { Sesudah }\end{array}$ & 33 & 10,166 & 45,184 \\
& 33 & 9,379 & 34,091 \\
\hline
\end{tabular}

Perbandingan rata-rata indeks plak gigi sebelum dan sesudah berkumur dengan sari tomat (Solamun lycopercsicum L.) dapat dilihat pada grafik batang berikut :

Grafik I Rata-rata Indeks Plak Gigi Sebelum dan Sesudah Berkumur dengan Sari Tomat (Solamun lycopercsicum L.) Hari ke-1, Hari ke-3 dan Hari ke-7

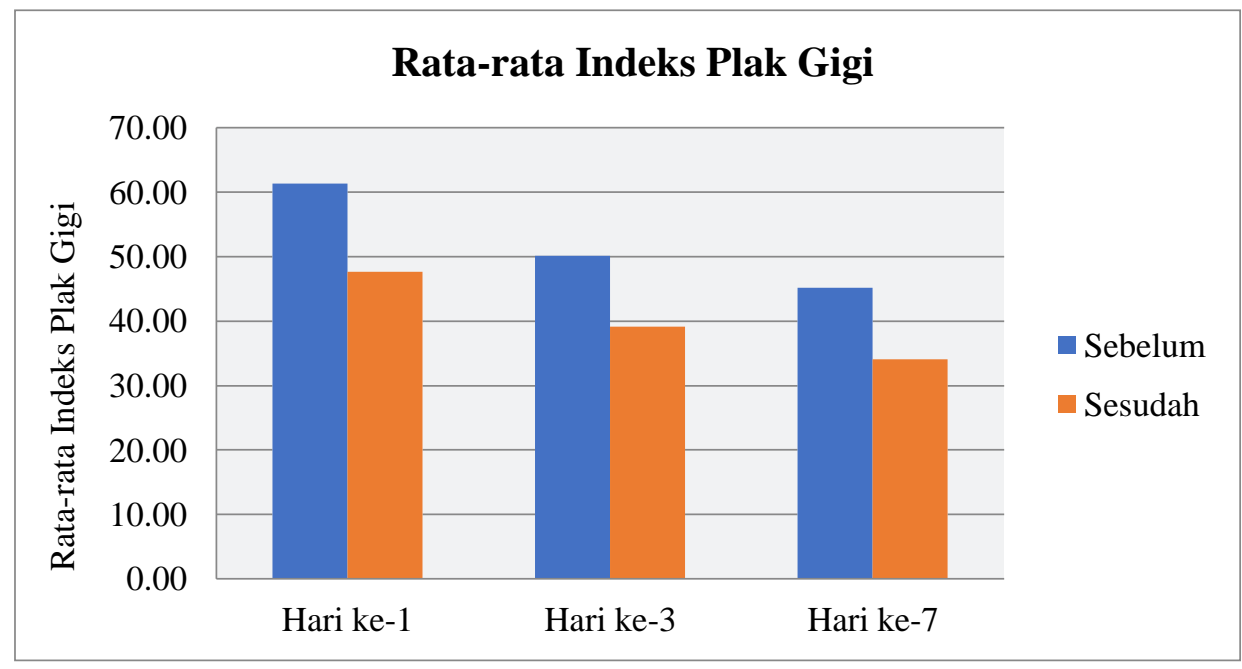


Tabel 4 menunjukkan perbandingan rata-rata penurunan indeks plak gigi pada 3 hari. Pada hari ke-1 memiliki rata-rata penurunan indeks plak sebesar 13,67 dengan nilai standar deviasi sebesar 8,293, pada hari ke-3 memiliki rata-rata penurunan indeks plak gigi sebesar 11,03 dengan nilai standar deviasi sebesar 4,941 dan pada hari ke-7 memiliki rata-rata penurunan indeks plak gigi sebesar 11,09 dengan nilai standar deviasi sebesar 4,429.

Tabel 4 Rata-rata Penurunan Indeks Plak Gigi dengan Sari Buah Tomat (Solamun lycopercsicum L.) pada Hari ke-1, Hari ke-3 dan Hari ke-7

\begin{tabular}{|c|c|c|c|c|c|}
\hline Hari & $\mathbf{N}$ & $\begin{array}{l}\text { Standar } \\
\text { Penurunan } \\
\text { Indeks Plak }\end{array}$ & Deviasi & $\begin{array}{l}\text { Rata-rata } \\
\text { Indeks } \\
\text { Plak }\end{array}$ & Penurunan \\
\hline $\begin{array}{l}\text { Hari ke- } \\
1\end{array}$ & 33 & 8,293 & & 13.67 & \\
\hline $\begin{array}{l}\text { Hari ke- } \\
3\end{array}$ & 33 & 4,941 & & 11.03 & \\
\hline $\begin{array}{l}\text { Hari ke- } \\
7\end{array}$ & 33 & 4,429 & & 11.09 & \\
\hline
\end{tabular}

Perbandingan rata-rata penurunan indeks plak gigi pada hari ke-1, hari ke-3 dan hari ke-7 dapat dilihat pada grafik batang berikut:

Grafik II Perbandingan Rata-rata Penurunan Indeks Plak Gigi dengan Berkumur Sari Buah Tomat (Solamun lycopercsicum L.)

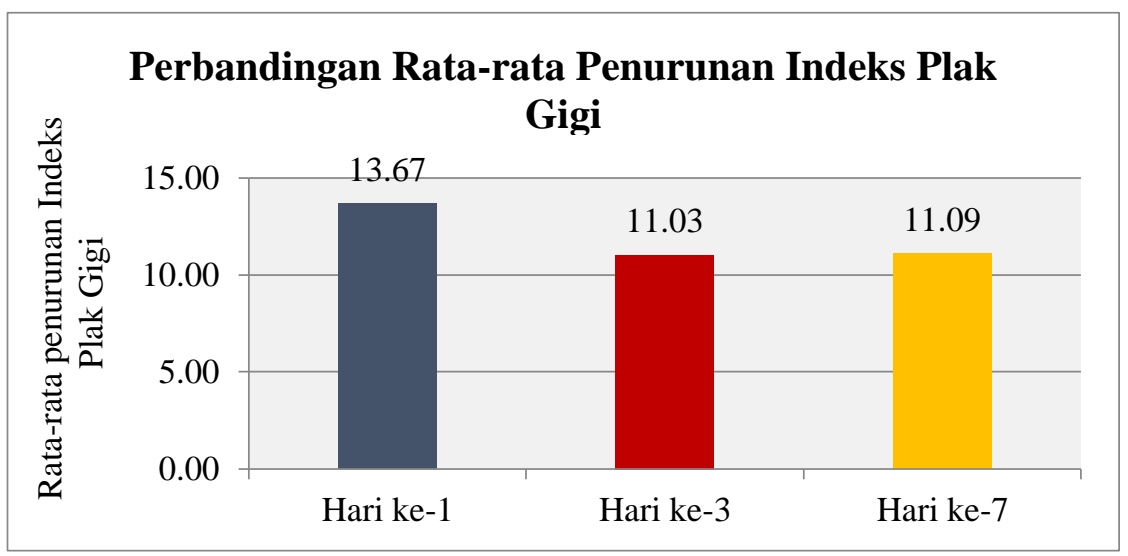

Tabel 5 menunjukkan perbandingan rata-rata penurunan indeks plak gigi karena waktu. Rata-rata penurunan indeks plak gigi hari ke-1 ke hari ke-3 sebesar 7,34 dengan nilai standar deviasi sebesar 6,39, rata-rata penurunan indeks plak gigi hari ke-3 ke hari ke-7 sebesar 4,83 dengan nilai standar deviasi sebesar 3,67 dan rata-rata penurunan indeks plak gigi hari ke-1 ke hari ke-7 sebesar 7,81 dengan nilai standar 
deviasi sebesar 7,53.

Tabel 5 Rata-rata Penurunan Indeks Plak Gigi dengan Berkumur Sari Buah Tomat (Solamun lycopercsicum L.) karena Waktu

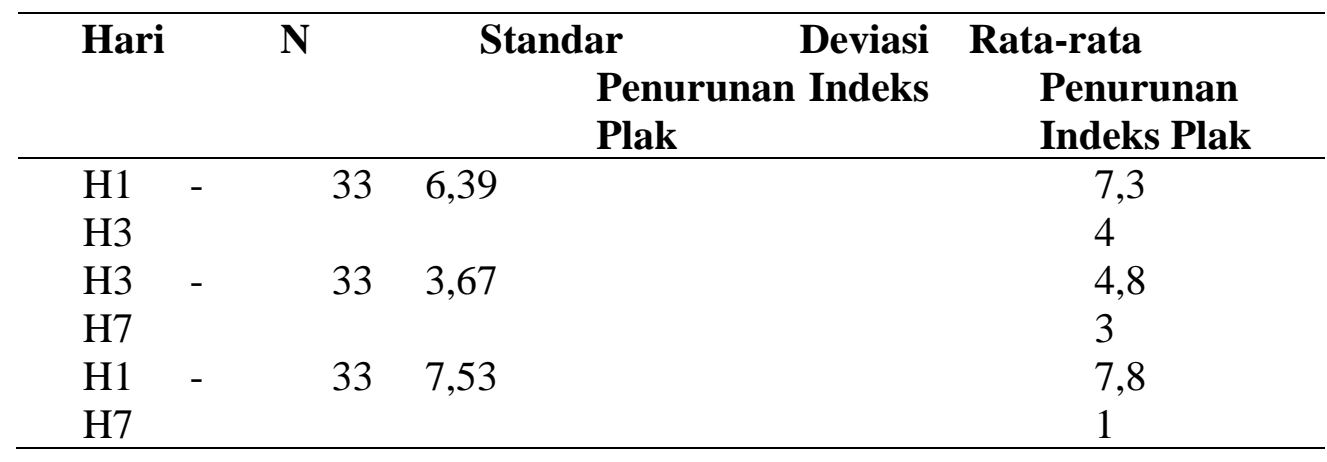

\section{Uji Normalitas Data}

Uji normalitas digunakan untuk menguji data berdistribusi secara normal atau tidak. Uji ini dengan uji One Sample Kolmogorov Smirnov jika jumlah data > 50 dan dengan uji signifikansi Shapiro-Wilk jika jumlah data $<50$. Pada penelitian ini digunakan uji Shapiro-Wilk karena sampel berjumlah 33 orang.

Dasar pengambilan keputusan pada uji normalitas ini adalah sebagai berikut:

- Jika angka signifikansi Uji Shapiro-Wilk >0,05 maka data berdistribusi normal

- Jika angka signifikansi Uji Shapiro-Wilk $<0,05$ maka data tidak berdistribusi normal.

Tabel 6 Hasil Uji Normalitas (Shapiro-Wilk) Indeks Plak Gigi Sebelum dan Sesudah Berkumur dengan Sari Buah Tomat (Solamun lycopercsicum L.)

\begin{tabular}{ll}
\hline \multicolumn{1}{c}{$\begin{array}{l}\text { Indeks } \\
\text { Gigi }\end{array}$} & $\begin{array}{l}\text { Sig. } \\
(p)\end{array}$ \\
\hline $\begin{array}{l}\text { Indeks plak gigi sebelum berkumur dengan sari tomat hari } \\
\text { ke-1 }\end{array}$ & 0,660 \\
$\begin{array}{l}\text { Indeks plak gigi setelah berkumur dengan sari tomat hari } \\
\text { ke-1 }\end{array}$ & 0,013 \\
$\begin{array}{l}\text { Indeks plak gigi sebelum berkumur dengan sari tomat hari } \\
\text { ke-3 }\end{array}$ & 0,126 \\
$\begin{array}{l}\text { Indeks plak gigi setelah berkumur dengan sari tomat hari } \\
\text { ke-3 }\end{array}$ & 0,024 \\
$\begin{array}{l}\text { Indeks plak gigi sebelum berkumur dengan sari tomat hari } \\
\text { ke-7 }\end{array}$ & 0,515 \\
$\begin{array}{l}\text { Indeks plak gigi setelah berkumur dengan sari tomat hari } \\
\text { ke-7 }\end{array}$ & 0,411 \\
\hline
\end{tabular}

Tabel 6 di atas menunjukkan bahwa hanya terdapat 2 variabel yang tidak berdistribusi normal yaitu variabel indeks plak gigi setelah berkumur dengan sari tomat hari ke-1 $(\mathrm{p}=0,013$ 
$<0,05)$ dan variabel Indeks plak gigi setelah berkumur dengan sari tomat hari ke-3 $(\mathrm{p}=0,024<0,05)$, sedangkan variabel lainnya berdistribusi normal dengan nilai signifikansi $\mathrm{p}>0,05$.

Tabel 7 Uji Normalitas Penurunan Indeks Plak Gigi Hari ke-1, Hari ke-3 dan Hari ke-7

\begin{tabular}{cllc}
\hline $\begin{array}{c}\text { Tests of } \\
\text { Normality }\end{array}$ & $\begin{array}{l}\text { Statisti } \\
\text { c }\end{array}$ & df & Sig. \\
\hline Hari ke-1 & 0,125 & 33 & 0,066 \\
Hari ke-3 & 0,101 & 33 & 0,488 \\
Hari ke-7 & 0,170 & 33 & 0,389 \\
\hline
\end{tabular}

Uji normalitas dengan Shapiro Wilks Test pada Tabel 7 diatas menunjukkan bahwa data penurunan indeks plak gigi berdistribusi normal ( $p>0,05)$.

Tabel 8 Hasil Uji Hipotesis Indeks Plak Gigi Sebelum dan Sesudah Berkumur dengan Sari Buah Tomat (Solamun lycopercsicum L.)

\begin{tabular}{lcll}
\hline & Kelompok & A & Sig. $(p)$ \\
\hline $\begin{array}{l}\text { Berkumur } \\
\text { hari ke-1 }\end{array}$ & dengan sari tomat & & \\
& $\begin{array}{c}\text { Sebelum } \\
\text { Sesudah }\end{array}$ & 0,0 & $0,000^{*}$ \\
$\begin{array}{l}\text { Berkumur } \\
\text { hari ke-3 }\end{array}$ & $\begin{array}{l}\text { dengan sari tomat } \\
\text { Sebelum }\end{array}$ & 0,0 & \\
& $\begin{array}{l}\text { Sesudah } \\
\text { Berkumur } \\
\text { hari ke-7 }\end{array}$ & 5 & $0,000^{*}$ \\
& Sebelum sari tomal & & \\
& Sesudah & 0,0 & $0,000^{*}$ \\
\hline
\end{tabular}

*Uji wilcoxon, **uji t berpasangan, 95\%

Berdasarkan hasil pengujian pada Tabel 8 diatas, diketahui bahwa terdapat perbedaan yang signifikan sebelum dan sesudah berkumur dengan sari tomat (Solamun lycopercsicum L.) pada hari ke-1 nilai p $0,000<\alpha(0,05)$, terdapat perbedaan yang signifikan sebelum dan sesudah berkumur dengan sari tomat (Solamun lycopercsicum L.) pada hari ke-3 nilai p $0,000<\alpha(0,05)$ dan terdapat perbedaan yang signifikan sebelum dan sesudah berkumur dengan sari tomat (Solamun lycopercsicum L.) pada hari ke-7 nilai p $0,000<\alpha(0,05)$. 
Tabel 9 Hasil Uji Hipotesis Penurunan Indeks Plak Gigi karena Waktu

\begin{tabular}{cll}
\hline $\begin{array}{c}\text { Kelomp } \\
\text { ok }\end{array}$ & A & \multicolumn{1}{c}{$\begin{array}{l}\text { Sig. } \\
(p)\end{array}$} \\
\hline Penurunan indeks plak (hari ke-1-ke-3) & $\begin{array}{l}0,0 \\
\text { Penurunan indeks plak (hari ke-1-ke-7) }\end{array}$ & 0,000 \\
& $\begin{array}{l}0,0 \\
\text { Penurunan indeks plak (hari ke-3-ke-7) }\end{array}$ & 5 \\
& 0,0 & 0,000 \\
& 5 & 0,000 \\
\hline
\end{tabular}

Berdasarkan Tabel 9, dapat dilihat bahwa terdapat penurunan indeks plak gigi yang signifikan pada hari ke-1 dan hari ke-3 dengan nilai p $0,000<\alpha(0,05)$, terdapat penurunan indeks plak gigi yang signifikan pada hari ke-1 dan hari ke-7 dengan nilai p $0,000<\alpha(0,05)$, dan terdapat penurunan indeks plak gigi yang signifikan pada hari ke-3 dan hari ke-7 dengan nilai p $0,000<\alpha(0,05)$.

Kesimpulan dari penelitian ini adalah berkumur sari buah tomat memiliki efek dapat menurunkan indeks plak gigi.

\section{Diskusi}

Plak gigi adalah lapisan biofilm yang melekat kuat pada permukaan gigi, restorasi, dan protesa. Plak terdiri dari bakteri, glikoprotein saliva dan polimer ekstraseluler. 5,6 Proses pembentukan plak dibagi menjadi 3 tahap yaitu pembentukan pelikel, kolonisasi awal mikroorganisme, kolonisasi sekunder dan maturasi mikroba. Pembentukan plak diawali dengan pembentukan pelikel gigi dimana pada tahap ini permukaan gigi akan dilapisi oleh pelikel glikoprotein. Pelikel tersebut berasal dari saliva, cairan sulkus, produk sel bakteri dan debris, dimana pelikel membantu meningkatkan adhesi atau perlekatan bakteri. Tahap kedua adalah kolonisasi awal oleh mikroba fakultatif gram positif yaitu Streptococcus mutans, Streptococcus sanguis, Streptococcus mitis dan Actinomyces viscosus. Bakteri ini melekat secara berbeda pada permukaan gigi yang dilapisi pelikel karena beberapa bakteri memiliki struktur perlekatan spesifik seperti zat polimer ekstraseluler, yang memungkinkan mereka untuk melekat cepat pada permukaan karena adanya interaksi reseptor pelikel gigi dan adesi dari permukaan bakteri. Tahap terakhir adalah kolonisasi sekunder dan maturasi mikroba. $P$. intermedia, $P$. gingivalis,

F. Nucleatum merupakan bakteri kolonisasi sekunder yang pada awalnya tidak mengkolonisasi

permukaan gigi yang bersih atau dilapisi pelikel. Bakteri ini melekat pada sel bakteri yang sudah ada dalam masa plak. Pada fase ini, ada koagregasi, yang merupakan kemampuan berbagai spesies mikroba plak untuk melekat satu sama lain. Fusobacterium nucleatum diyakini menjadi penyambung yang penting antara kolonisasi awal dan sekunder selama pematangan plak. ${ }^{8}$

Bakteri utama dalam plak gigi adalah Streptococcus sangui, Streptococcus mutans, 
dan Actinomyces viscosus. Studi lain menunjukan bahwa pada awal formasi atau pembentukan plak gigi, Streptococcus mutans, Streptococcus sanguis, Streptococcus mitis, Streptococcus salivarius paling banyak ditemukan. 9,10

Streptococcus mutans telah lama terlibat dalam pembentukan plak gigi dimana menempel dengan ikatan hidrofobik ke permukaan enamel. ${ }^{11}$ Streptococcus mutans mampu mensintesis polisakarida ekstraseluler karena bakteri ini mempunyai enzim glukosiltransferase (GTF) yang terdapat pada dinding sel bakteri Streptococcus mutans yang dapat mengatalisis sintesis glukan dari sukrosa. ${ }^{12}$ Glukan merupakan sumber energi utama bagi bakteri dan memperkuat perlekatan permukaan bakteri pada komponen pelikel gigi. 13

Plak yang dibiarkan terlalu lama dapat menyebabkan karies dan penyakit periodontal. Cara menjaga kebersihan gigi dan mulut adalah dengan pengendalian plak yang melekat pada permukaan gigi atau gingiva dan membersihkan plak gigi secara teratur. Saat menghambat pembentukan plak, maka secara langsung akan menghambat pembentukan kalkulus, sehingga jaringan periodontal menjadi sehat. ${ }^{14}$ Salah satu cara pengendalian plak adalah dengan berkumur menggunakan obat kumur dari bahan alami yaitu sari buah tomat.

Obat kumur merupakan obat yang mengandung suatu bahan aktif yang dapat menghambat pertumbuhan dan perkembangan bakteri. Pada kontrol plak sehari-hari, obat kumur digunakan sebagai bahan tambahan untuk menyingkirkan plak secara kimiawi. Hal ini disebabkan berkumur dengan obat kumur dapat mengjangkau daerah-daerah yang sulit dibersihkan.

Tomat (Solanum lycopersicum L.) mengandung senyawa tannin dan flavonoid yang merupakan senyawa yang memiliki potensi antibakteri. Tannin memiliki sifat antibakteri dalam pembentukan biofilm dan aktifitas antibiofilm dalam suatu kolonisasi dan mencegah perlekatan

$S$. mutans ke permukaan gigi dengan cara mengurangi hidrofobisitas dari badan sel bakteri. $^{20,21}$

Flavonoid memiliki efek antibakteri bakteriostatik dengan menghambat enzim glukosiltransferase (GTF) sehingga mengurangi perlekatan dan pembentukan koloni Streptococcus mutans yang mengatalisis sintesis glukan dari sukrosa. ${ }^{12,19}$ Menurut penelitian, ditemukan bahwa flavonoid menghambat pembentukan plak dengan menunjukan penurunan yang signifikan pada streptokokus gram positif. ${ }^{24}$

Pada penelitian yang telah dilakukan oleh penulis memperlihatkan bahwa zat yang terkandung dalam tomat terbukti memiliki daya antibakteri yang dapat menurunkan indeks plak gigi sehingga dapat mencegah terjadinya penyakit periodontal. Penelitian ini dilakukan pada 33 subjek dan rerata penurunan nilai indeks plak gigi setelah berkumur sari buah tomat pada hari pertama 13,67, rerata penurunan nilai indeks plak gigi setelah berkumur sari buah tomat pada hari ketiga 11,03 dan rerata penurunan nilai indeks plak gigi setelah berkumur sari buah tomat pada hari ketujuh adalah 11,09. Terdapat variasi selisih indeks plak gigi sebelum dan setelah berkumur sari buah tomat dengan nilai tertinggi 13,67 dan terendah 11,03. Adanya variasi hasil penelitian nilai indeks plak gigi disebabkan karena beberapa faktor, seperti teknik menyikat gigi, kondisi gigi dan rongga mulut yang berbeda-beda pada setiap subjek penelitian, makanan yang dikonsumsi dan cara berkumur.

Rata-rata penurunan indeks plak gigi tertinggi pada hari ke-1 dapat disebabkan 
karena mekanisme kerja obat kumur yang membersihkan rongga mulut secara mekanik dan kimiawi yang dapat mencapai lebih banyak permukaan-permukaan rongga mulut. Gerakan berkumur dapat menggerakan otot pipi sehingga bahan kumur yang digunakan secara mekanis dapat melepaskan partikel-partikel debris yang banyak mengandung bakteri, sedangkan secara kimiawi disebabkan efek kandungan antibakteri dari tomat. ${ }^{49,50}$

Penurunan rata-rata indeks plak gigi dari hari ke-1 ke hari ke-3 dapat disebabkan karena bakteri pada plak gigi memiliki resistensi yang kuat terhadap agen antibakteri karena polisakarida ekstraseluler yang terdapat pada bakteri mencegah perfusi agen antibakteri ke bakteri. Perlindungan ini melindungi bakteri plak melawan lingkungan tertentu seperti antibiotik, antibodi, bakteriofag dan sel darah putih. ${ }^{51}$ Peningkatan dari rata-rata penurunan indeks plak gigi dari hari ke-3 ke hari ke-7 dapat disebabkan karena variasi gerakan berkumur dan fungsi otot-otot bibir, lidah dan pipi. 50

Hasil uji statistik pada Tabel 7 menunjukan bahwa nilai p $(0,000)$ bahwa terdapat perbedaan yang signifikan $(p$-value $<0,05)$ dan berarti $\mathrm{H}_{0}$ ditolak. Berdasarkan analisis tersebut maka $\mathrm{H}_{1}$ diterima, yaitu terdapat perbedaan presentasi rata-rata indeks plak gigi sebelum dan sesudah berkumur sari buah tomat (Solanum lycopersicum L.). Oleh karena itu, dapat disimpulkan bahwa berkumur sari buah tomat (Solanum lycopersicum L.) memiliki efek dapat menurunkan indeks plak gigi.

\section{Kesimpulan}

Berdasarkan hasil penelitian dapat disimpulkan bahwa berkumur sari buah tomat (Solanum lycopersicum L.) memiliki efek dapat menurunkan indeks plak gigi.

\section{Referensi}

1. Prayitno, Adi. Kelainan gigi dan jaringan pendukung gigi yang sering ditemui. 2008;7(35):411.

2. Nazir, M. A. Prevalence of periodontal disease, its association with systemic disease and prevention. IJHS. 2017;1(2):72.

3. Tuhuteru, D. R., Lampus, B. S., and Wowor, V. N. S. Status kebersihan gigi dan mulut pasien poliklinik gigi puskesmas paniki bawah manado. Jurnal e-Gigi. 2014;2(2).

4. Sugano N. Biological plaque control: Novel therapeutic approach to periodontal disease.J Oral Sci. 2012;54(1):1-5.

5. I.R. Ion, Victoria C. Dental plaque - Classification, formation, and identification. Int J Med Dent. 2013;3:139-143.

6. Roth I. G \& Calmes. R. Oral biology. St.Louis: Mosby; 1981:329,332-335.

7. Reca., Ainun M., Cut N. Pengaruh berkumur dengan larutan teh hijau terhadap indeks plak pada murid kelas vi sdn 62 banda aceh tahun 2015. 2015;2(2):67.

8. Bathla, Shalu. Periodontics revisited. $1^{\text {st }}$ ed. New Delhi: Jaypee Brothers Medial 
Publisher; 2011:67-68.

9. Marsh, Philip. Dental plaque as a biofilm and a microbial community implicatons for health and disease. BMC Oral Health. 2006;6(1):14.

10. Nurin A., Oedijani S. Inhibition of dental plaque formation by toothpaste containing propolis. Dental Journal. 2012;45(4):209.

11. Prabu G., Gnanamani A. Guaijaverin - A plant flavonoid as potential antiplaque agent against streptococcus mutans. J Appl Microbiol. 2006:487.

12. Isnarianti R., Wahyudi I. A., Puspita R. M. Muntingia calabura 1 leaves extract inhibit glucosyltransferase activity of streptococcus mutans. J Dent Indones. 2013;20(3):59-63.

13. Samaranayangke L. Essential microbiology for dentistry. $3^{\text {rd }}$ ed. Philadelphia: Churchill Livingstone Elsevier; 2006:273,282.

14. Balagopal S, Arjunkumar R. Chlorhexidine: The gold standard antiplaque agent. J Pharm Sci Res. 2013;12(5):270-274.

15. Doris J. Stiefel. Dental care consideration for disable adults. 2002;22(3)\&26.

16. Rajan S., Ravi J., Suresh A., Guru S. Hidden secrets of "punica granatum" use and its effect on oral health: A short review. JOFR. 2013;3(1):38-41.

17. Kirstie C, Jessica K, Campbell, Susan Z, Elizabeth H., John W. The tomato as a functional food. The Journal of Nutrition. 2005;135(5):1226-1230.

18. Bhowmik, D., Sampath, K., Shravan, P., Shweta, S. Tomato - A natural medicine and its health benefits. J Pharmacogn and Phytochem. 2012;1(1):35.

19. Raiola, A., M. M. Rigano, R. Calafiore, L. Frusciante, and A. Barone. Enhancing the health-promoting effects of tomato fruit for biofortified food. Mediators of Inflammation. 2014. [cited 04 Januari 2018]. Available from URL: https://www.ncbi.nlm.nih.gov/pmc/articles/PMC3972926/

20. Dong G, Liu H, Yu X, Zhang X, Lu H, Zhou T, et al. Antimicrobial and antibiofilm activity of tannic acid against staphylococcus aureus. Nat Prod Res. 2018;32(18):2225-8.

21. Krzyściak W, Jurczak A, Kościelniak D, Bystrowska B, Skalniak A. The virulence of streptococcus mutans and the ability to form biofilms. Eur J Clin Microbiol Infect Dis. 2014;33(4):499-515.

22. Bassoon, Miranda, Wyk. The effect of areca nut on salivary and selected oral microorganism. Vancouver, 1996;46(4):350-6. Available from URL : https://www.ncbi.nlm.nih.gov/pubmed/9147124 
23. Dian E, Mochamad F, Sarworini B. Antiacterial effect of flavonoid from propolis produced by atpase activity of streptococcus mutans. Int J Appl Pharm. 2017; $9(2)$.

24. Sankari S, Babu A, Rani V, Priyadharsini C. Flavonoids clinical effects and applications in dentistry: A review. J Pharm Bioallied Sci. 2014;6(1):26-29.

29. Newman M. G., Takei H. H. Klokkevold P. R. Carranza's clinical periodontology. $10^{\text {th }}$ ed. Philadephia: Saunders Elsevier, 2006:137-138,144$145,728-744$.

30. Newman M. G., Takei H. H., Carranza F. A., Klokkevold P.R. Carranza's clinical periodontology. $9^{\text {th }}$ ed. St. Louis: WB Saunders Company, 2002:97-149.

31. Kidd E. Essential of dental caries. $3^{\text {rd }}$ ed. London: Oxford University Press; 2005:16,76.

32. Nagoba, B. S. Microbiology for dental students. New Delhi: BI Publications Pvt Ltd; 2007:61-62.

36. Center of Scientific Information. Mouthwash (Mouthrinse). ADA. 2017.

37. Rateitschak KH, Rateitschak EM, Wolf HF, Hassel TM. Color atlas of periodontology. $3^{\text {rd }}$ ed. New York: Thienne Inc; 2005:27-29.

38. Hidayati, Nurul., Dermawan, Rahmansyah. Tomat unggul. Jakarta: Penebar Swadaya. 2012:6.

39. Dinarwi. Pengaruh lama penyimpanan dan jenis pengemas terhadap kadar gula dan keasaman buah tomat (Lycopersicon esculentum Mill). Biro Litbang Industri. 2011;46(1):21-29.

40. Madkar, Oktap Ramlan., Saiduna. Pengaruh suhu dan tingkat kematangan buah terhadap mutu dan lama simpan tomat (Lycopersicon esculentum Mill). Jurnal Argoswagati. 2013;1(1):44.

41. Harijadi, S.S., Sunarjono, H. Budidaya tomat: Dasar-dasar holtikultura. Fakultas Pertanian Institut Pertanian Bogor. 1990:13-14.

42. Desrosier, N. W. Teknologi pengawetan pangan. $3^{\text {rd }}$ ed. Jakarta: Universitas Indonesia. 1988:35-63.

45. Raiola, Assunta., Rigano, M.M., Calafiore, Roberta., Frusciante, Luigi., Barone, Amalia. Enhancing the health promoting effect of tomato fruit for biofortified food. Mediators of Inflammation. 2014:139873.

49. Patabang, W.A., Leman, M.A., Maryono, J. Perbedaan jumlah pertumbuhan 
koloni bakteri rongga mulut sebelum dan sesudah menggunakan obat kumur yang mengandung chlorheksidine. Pharmacon Jurnal Ilmiah Farmasi. 2016;5(1):26-31.

50. Nasri., Imran, Herry. Efektifitas berkumur dengan larutan teh rosella dalam menghambat plak gigi serta mempercepat penyembuhan gingivitis pasca scaling. Aceh Nutrition Journal. 2017;2(1):18-24.

51. Yu, OY., Zhao, IS., Mei, ML., Lo, EC., Chu, C. Dental biofilm and laboratory microbial culture models for cariology research. Dent J. 2017;5(21):1-12. 